\title{
Analysis of Sustainable Energy Systems in Ecovillages: A Review of Progress in BedZED and Masdar City
}

\author{
Dan Zhu', Michael Kung'2, Liang Zhou ${ }^{3,4}$ \\ ${ }^{1}$ College of Design, Construction and Planning, University of Florida, Gainesville, USA \\ ${ }^{2}$ College of Education, University of Florida, Gainesville, USA \\ ${ }^{3}$ School of Geographic and Oceanographic Sciences, Nanjing University, Nanjing, China \\ ${ }^{4}$ Department of Geography, Indiana University, Bloomington, USA \\ Email: zhudan@ufl.edu
}

Received 20 January 2015; accepted 6 February 2015; published 9 February 2015

Copyright (C) 2015 by authors and Scientific Research Publishing Inc.

This work is licensed under the Creative Commons Attribution International License (CC BY). http://creativecommons.org/licenses/by/4.0/

\section{(c) (i) Open Access}

\begin{abstract}
This paper explores sustainable energy systems in ecovillages based on the concept of the Zero Energy Building. The cases discussed in this paper include BedZED in the United Kingdom and Masdar City in the Middle East. These two communities contain features characterized by the sustainable principles of the ecovillage concept by using renewable energy and reclaimed materials to reach a low/zero energy system in buildings. The creation of more ecovillages and the growth of current ecovillages play an important role in positively solving environmental and social problems. The low energy buildings in the ecovillages also act as a model for communities wishing to implement sustainable development.
\end{abstract}

\section{Keywords}

Zero Energy Building, Renewable Energy, Sustainable Development, Ecovillage, Reclaimed Materials

\section{Introduction}

By 2050, the world's population is expected to reach 9.6 billion, with some projections estimating as high as 10.9 billion [1]. With even today's population, buildings already consume over $40 \%$ of the energy in the US, which accounts for about $70 \%$ of the electricity produced [2]. With projections such as this, energy considerations form a crucial aspect that need to be addressed when preparing for the future; thus, many officials, plan- 
ners, and developers are turning to sustainable energy. Sustainable energy is concerned with energy use, especially with the ability to meet current needs, while not interfering with the demand of future energy use. Sustainable energy commonly includes the use of solar energy, wind energy, biomass plants, tide power, and many other kinds of renewable energy. The concept of a Zero Energy Building, a building that produces as much energy as it consumes, originally started appearing in the late 1970s and early 1980s, but is now being accepted as a serious and realistic solution for the reduction of energy use, especially within the building sector [2] [3]. In the US, the Energy Independence and Security Act of 2007, and in Europe, the Directive on Energy Performance of Buildings in 2010, both discussed and set goals for the implementation of ZEBs [2]. Many construction projects are now focused on becoming low or zero energy buildings; this complicated project requires careful analysis, design, implementation, and evaluation. Two well-known examples of comprehensive projects towards developing a sustainable community are the Beddington Zero (fossil) Energy Development (BedZED) in the UK and Masdar City in the Middle East.

\section{Beddington Zero Energy Development (BedZED)}

Brightly colored wind cowls facing the wind and photovoltaic panels are some of the features that a visitor might first notice when approaching the largest United Kingdom ecovillage of the Beddington Zero (fossil) Energy Development (BedZED) (Figure 1). However, these components play a critical part in BedZED's goal to reduce its environmental impact and create true zero energy houses and workspaces. BedZED is located in the London borough of Sutton, near the edge of the city. This sustainable community was led by The Peabody Trust, in partnership with Bill Dunster Architects and environmental consultants BioRegional.

\subsection{Sustainability}

One of BedZED's sustainability objectives was reduced environmental impact. Some of the original community plans included zero fossil fuel, $100 \%$ renewable energy use, zero heating homes, passive solar heating, PV power for 40 electric vehicles, wind-powered ventilation systems, low embodied energy materials, recycled timber, reused structural steel, and urban tree waste bio-fueled CHP [4] (Figure 2). For example, the buildings were designed to be energy efficient that stored heat when it was warm and released heat when it was cold so as to eliminate the need for central heating; a green transport plan was also implemented to minimize the residents' use of vehicles requiring fossil fuels, as well as the need to commute to work [2].

BedZED was designed to be carbon neutral, meaning it should generate enough renewable energy on-site for heating, hot water, and electrical uses. BedZED's design to rely only on solar, wind, and biomass energy was successful up to a point. Some of this can be attributed to homeowner education and willingness to change lifestyles and reduce energy use, in conjunction with energy-efficient and hot-water saving appliances. Homeowners were reported to use $45 \%$ lower electricity and $81 \%$ less hot water than the borough average [5]. $777 \mathrm{~m}^{2}$ of photovoltaic (PV) panels line the rooftops and south facing second floor windows [5]. Wind cowls on the roof harness the wind to create a healthy, well ventilated internal environment [6].

Materials used in the construction of BedZED were carefully selected for low environmental impact, so that the building materials were sourced locally, reclaimed, and/or recycled whenever possible. For example, all wood used was approved by the Forest Stewardship Council to guarantee they came from a sustainable source. This approach during the construction stage is reported to have reduced the environmental impact of BedZED by $20 \%-30 \%[6]$.

\subsection{Energy Systems}

One of the main sources for renewable energy in BedZED was designed to be generated by a custom biomass combined heat and power (CHP) plant using local wood fuel to generate both heat for hot water and electricity. The CHP plant operated by having woodchips fed into a dryer, which operated on waste heat from the generator engine. The woodchips were then transferred to a gasifier, where heating them converted them into a combustible gas (gasification process). The gas was then cleaned, cooled, mixed with air and fed into a spark ignition engine (Figure 3) [5].

Although the CHP plant was operational for a while, it now lies abandoned. The new, experimental equipment required constant modifications and full time maintenance. Unforeseen issues such as the reliability of equipment, tar condensing from the wood gas, and staffing requirements to operate led the plant to be shut down 


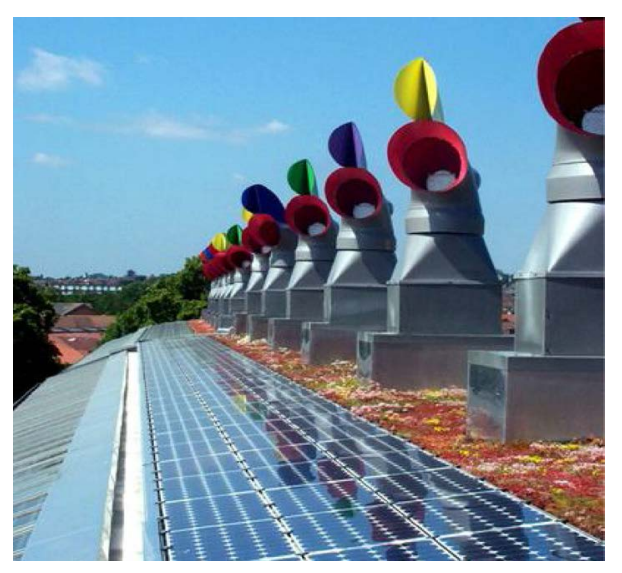

Figure 1. BedZED overhead view. Source: www.flickr.com/photos/53532973, 2007.

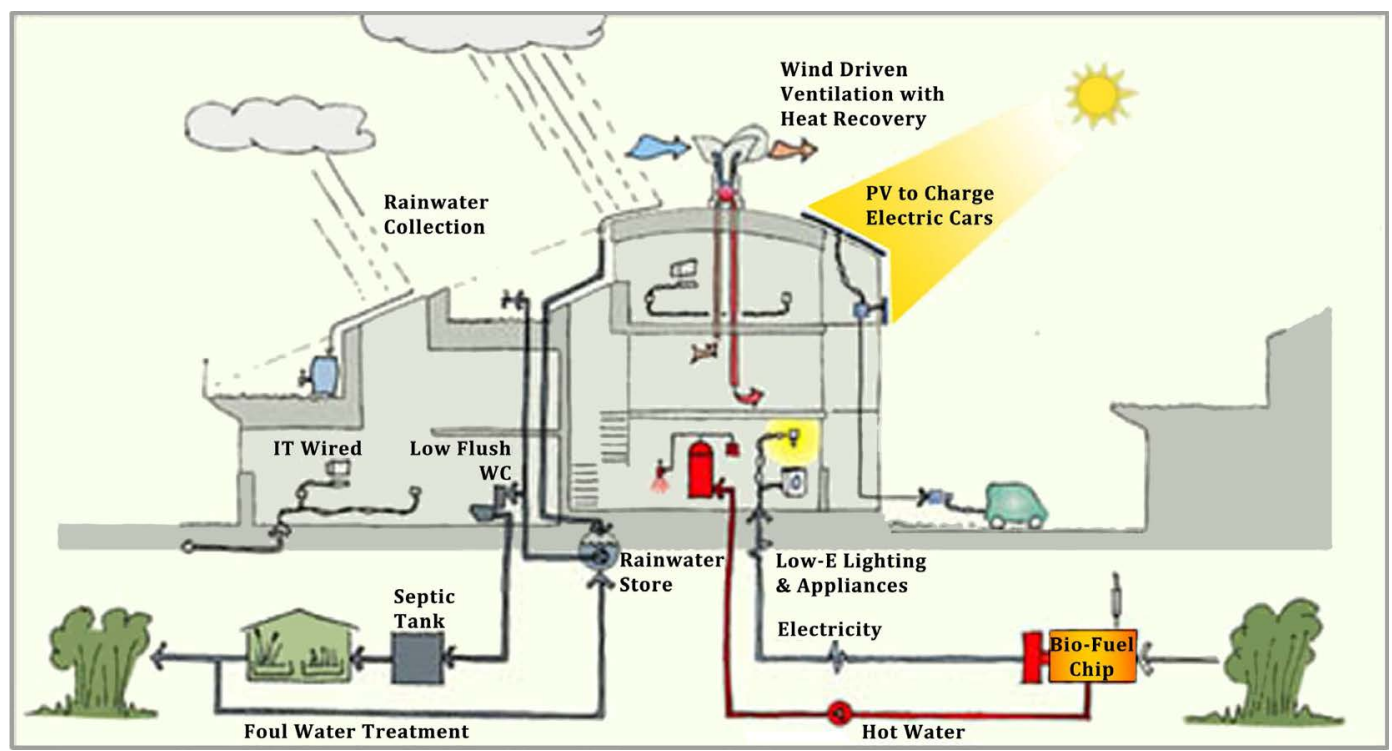

Figure 2. BedZED zero energy system. Adapted from: bioregional.com, 2002.

[5]. The costs required to run such a small scale plant were simply unfeasible. Because the CHP is no longer in operation, hot water for the community is produced by a gas condensing boiler, and most electricity is supplied by the national grid; the PV panels only supply about $20 \%$ of BedZED's demand [5].

\subsection{Guidance for Others}

Study results show that although residents in BedZED are unable to achieve a one planet living level ecological footprint, and even with the inoperable CHP plant, the energy consumption in the homes is much lower than the UK average [5] [7]. While it may not have met the original goals, BedZED was still an important step in the right direction towards a sustainable future; the positive results of BedZED led BioRegional to publish a Toolkit for Carbon-Neutral Developments [7].

This Toolkit is a practical guide on producing carbon neutral developments that minimize environmental impacts while still remaining profitable, including technical descriptions, monitoring results, and financial mechanisms that allowed BedZED to become a reality [7] [8]. Of special note is the BedZED Construction Materials Report that goes into detail about every aspect of construction in terms of its environmental impact. It covers the extracting, processing, and transporting of construction materials and explains how to deal with construction waste [7]. 


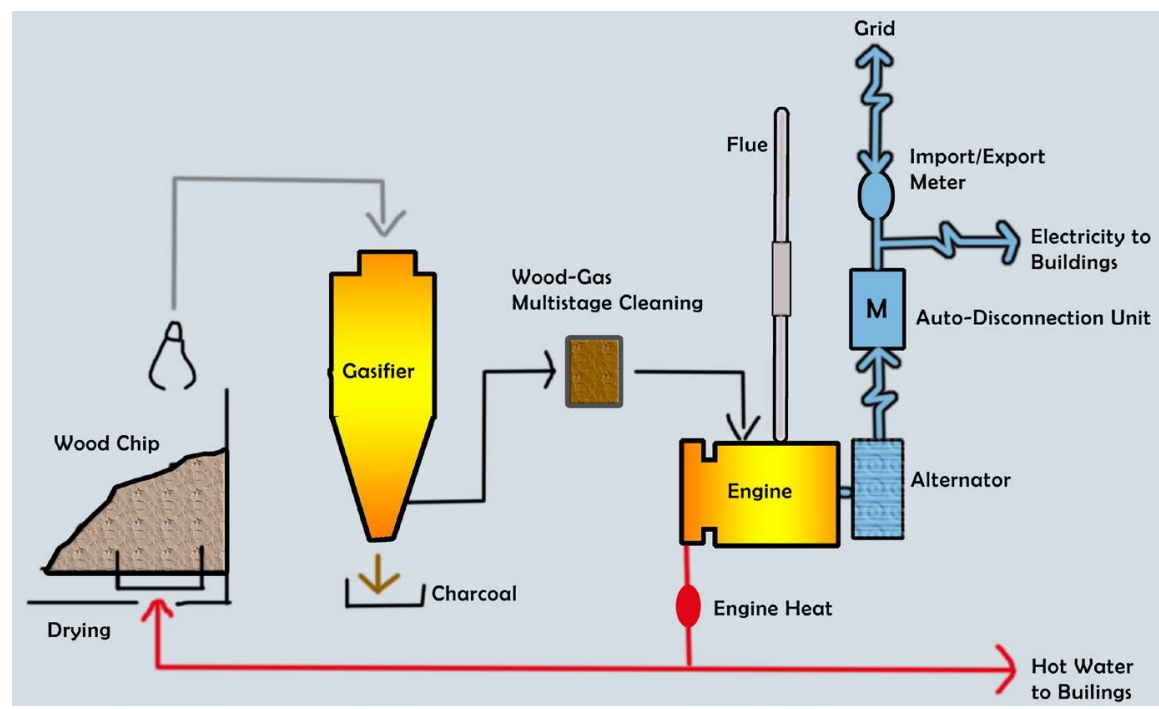

Figure 3. Combined heat and power (CHP) plant. Adapted from: BioRegional [5].

\section{Masdar City}

Another example that illustrates sustainable energy use is the Masdar City project in Abu Dhabi, designed by British architecture firm Foster + Partners (Figure 4). Masdar City, a low environmental waste community, was intended to be the first carbon-neutral city in the world, with the area of 6 sq. km and numerous renewable energy and eco-city plans applied in various ways [9] [10]. The buildings here use 54\% less water and 56\% less energy than similarly-sized conventional buildings through the combined use of both new, efficient technology and passive technology [11]. Though the original plan for the city was to support 40,000 people by 2016, the global financial crisis has delayed construction and will require many more years [11]. Despite this setback, the sustainable energy designs can be seen in examples throughout the city already.

\subsection{Energy}

Masdar City's power infrastructure includes a mixed system of renewable energy options, such as a "range of photovoltaic plants (PV), a concentrating solar thermal power plant (CSP), evacuated thermal tube collectors, and a waste-to-energy plant” ([12], p. 3953). For instance, consider how the city manages hot water. Masdar City's hot water is usually provided by photovoltaic electricity; in addition, solar collection through evacuated tubes has also been used to support the hot water when needed. Moreover, geothermal heat has been tested as an optional use in cold weather seasons. Masdar City is the home of the largest photovoltaic plant among the Middle East, generating up to $10 \mathrm{MW}$ from two main modules, a polycrystalline photovoltaic module and thin film photovoltaic module; these serve the Masdar administration and institute buildings, as well as provide energy for the onsite construction. A 1 MW solar photovoltaic plant on the roof of the Masdar Institute provides some of the solar power in this city, with the remaining energy coming from 88,000 photovoltaic panels on a solar farm [10].

However, there is a prediction that the energy needs will be increased along with the growth of this city. That is to say, the innovation of these renewable energy technologies will be hard-pressed to keep up with the expanded community energy use [13] [14]. In order to maintain its sustainable low energy waste, multiple renewable energy projects are being considered to provide this city with clean energy sources.

\subsection{Building Design}

Masdar City plans include mixed-use and low-rise buildings. The buildings have been designed in several ways to implement the zero energy system. $95 \%$ of the roofs have been installed with solar panels, and $90 \%$ of the buildings have green roofs. $85 \%$ of the building roofs have both solar panels and green roofs [12]. These two components not only generate energy but also regulate temperature and provide shading for pedestrians (Figure 5). 


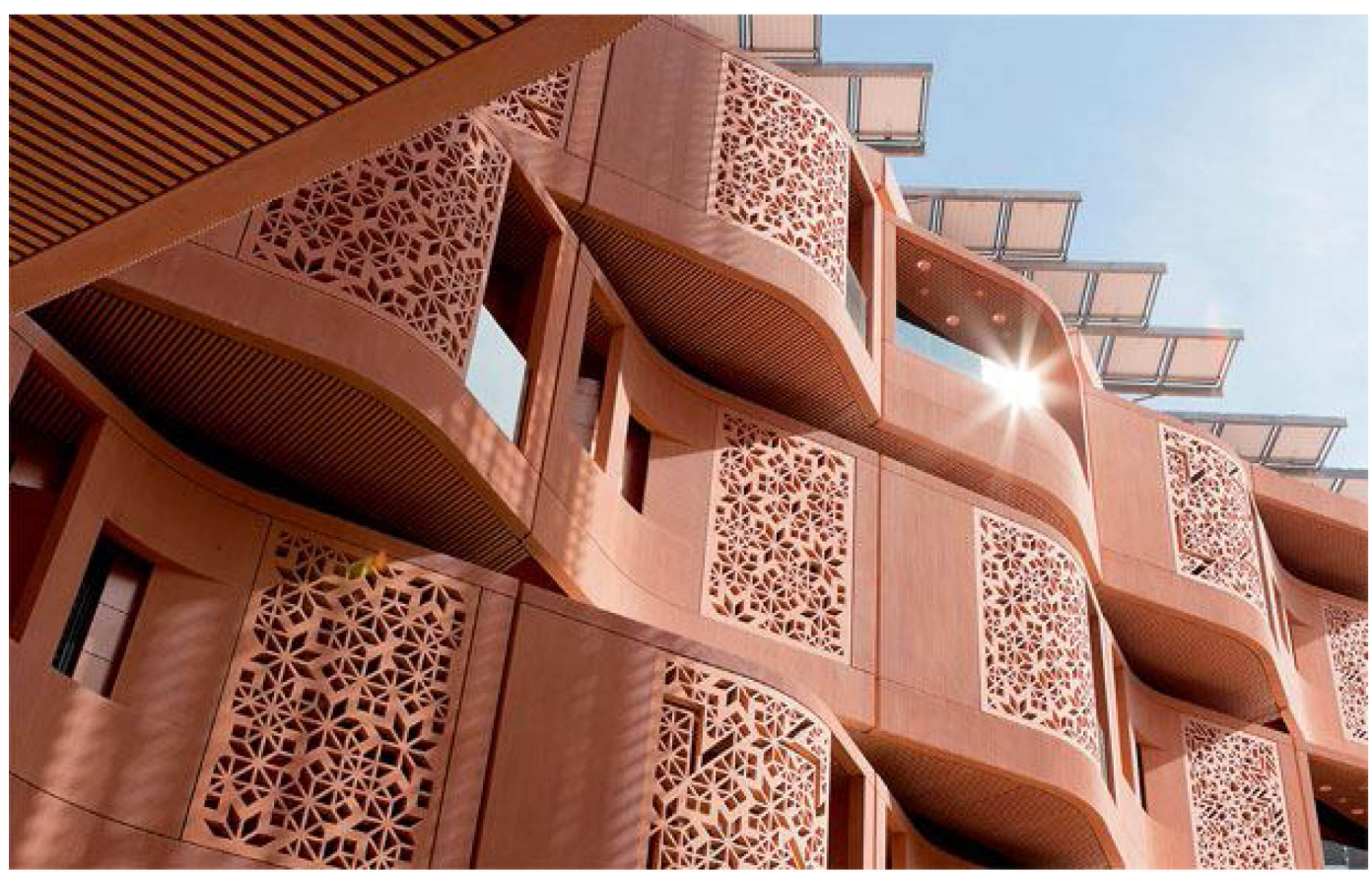

Figure 4. Ground views of Masdar City. Source: khaleejtimes.com/images/energy26072013.jpg.

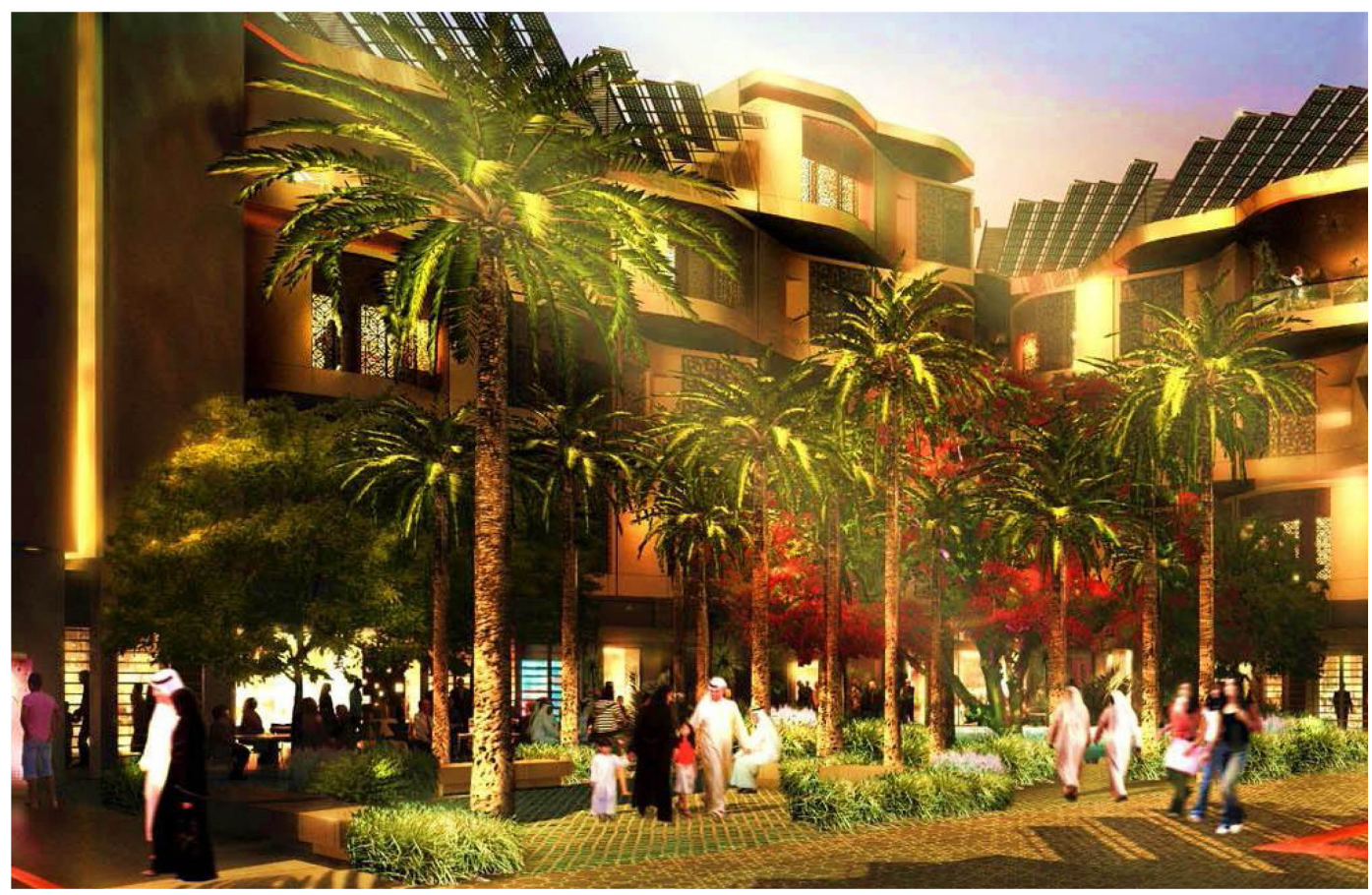

Figure 5. Rendering of sustainable systems. Source: dubaichronicle.com/wp-content/uploads/2009/10/MasdarInstitute2.jpg.

While not fully completed yet, the early buildings constructed here are plentiful with sustainable ideas. For example, in the Masdar Institute, sandstone inwardly slopes on the building facades, which allow the light to go through into the building. In addition, the sandstones function as building insulation blocks and maintain the building's comfort level [9] [11]. Photovoltaic panels on the roofs power the buildings, and a central tower displays the energy use [9]. Auditorium and cafes built in this building provide the building's mixed use and 
creates convenience for students [9]. Other major building technologies include interior natural ventilation, floor heat strategies, and shading strategies. All these concepts reduce building energy demand and help create buildings with low energy systems in long run.

\section{Conclusion}

Sustainable communities are crucial for the future of the world, especially with the predicted population rates. Zero Energy Buildings positively solve environmental and social problems in a scientific way. Strategically applied renewable energy systems allow for the highest quality of life at present and in the future. It is important for the world to start planning and managing energy use; realistically, planners and developers need to seek maximum efficiency gains while still allowing for profit. BedZED and Masdar City are just two such examples of sustainable communities. While none are perfect, they are on the right track to help manage the world's future energy use while still maintaining a high quality of life.

\section{References}

[1] United Nations, Department of Economic and Social Affairs, Population Division (2013) World Population Prospects: The 2012 Revision, Volume I: Comprehensive Tables. http://esa.un.org/wpp/documentation/pdf/WPP2012_Volume-I_Comprehensive-Tables.pdf

[2] Marszal, A.J., et al. (2011) Zero Energy Building-A Review of Definitions and Calculation Methodologies. Energy and Buildings, 43, 971-979. http://dx.doi.org/10.1016/j.enbuild.2010.12.022

[3] Torcellini, P. (2014) Getting to Net Zero. ASHRAE Journal, 56, 25.

[4] Twinn, C. (2003) BedZED. Arup Journal, 38, 10-16.

[5] Hodge, J. and Haltrecht, J. (2010) BedZED Seven Years on: The Impact of the UK's Best Known Eco-Village and Its Residents. BioRegional Development Group, UK.

[6] Lazarus, N. (2006) Toolkit for Carbon Neutral Developments. Vol. 2, BioRegional Development Group, UK.

[7] Beatley, T. (2012) Green Cities of Europe: Global Lessons on Green Urbanism. Island Press, Washington DC. http://dx.doi.org/10.5822/978-1-61091-175-7

[8] Lazarus, N. (2002) Beddington Zero (Fossil) Energy Development. BioRegional Development Group, UK.

[9] Best, R. (2011) Masdar City. http://robswatsonadventure.blogspot.com/2011/03/masdar-city.html

[10] Watts, B. (2010) Masdar to Be Scaled Down? BGreen Magazine. http://www.bgreen.ae/masdar-to-be-scaled-down-2/

[11] Patel, P. and Griffiths, S. (2013) Masdar City Showcases Sustainability. MRS Bulletin, 38, 450-451. http://dx.doi.org/10.1557/mrs.2013.140

[12] Nader, S. (2009) Paths to a Low-Carbon Economy-The Masdar Example. Energy Procedia, 1, 3951-3958. http://dx.doi.org/10.1016/j.egypro.2009.02.199

[13] Stacey, K. (2010) Masdar: “No Silver Bullet” for Problems Facing Cleantech City. Energy Source. http://blogs.ft.com/energy-source/2010/10/27/masdar-no-silver-bullet-for-problems-facing-cleantech-city/

[14] Bullis, K. (2009) A Zero-Emissions City in the Desert. Technology Review, March/April. 
Scientific Research Publishing (SCIRP) is one of the largest Open Access journal publishers. It is currently publishing more than 200 open access, online, peer-reviewed journals covering a wide range of academic disciplines. SCIRP serves the worldwide academic communities and contributes to the progress and application of science with its publication.

Other selected journals from SCIRP are listed as below. Submit your manuscript to us via either submit@scirp.org or Online Submission Portal.
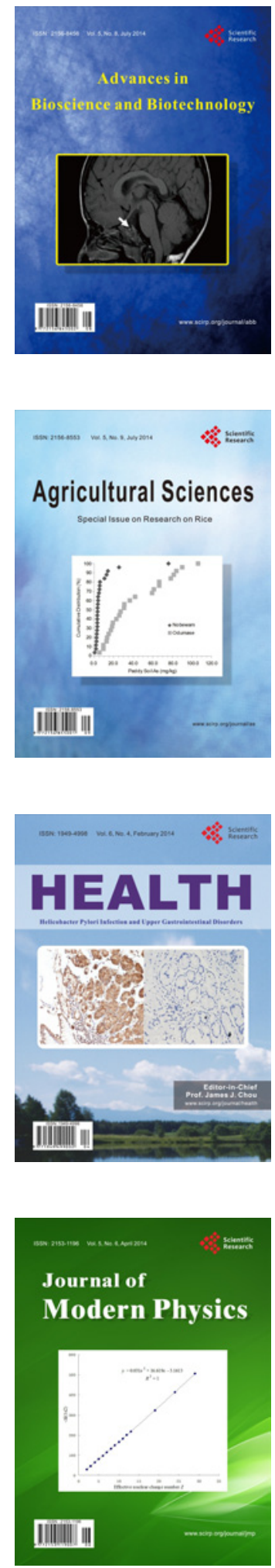
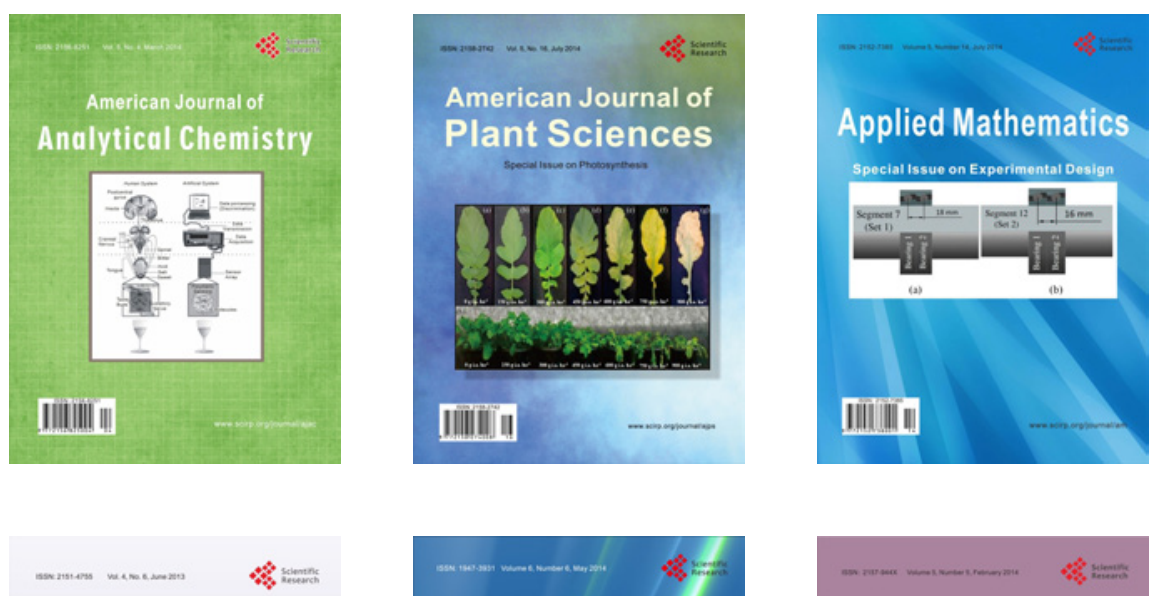

Creative Education
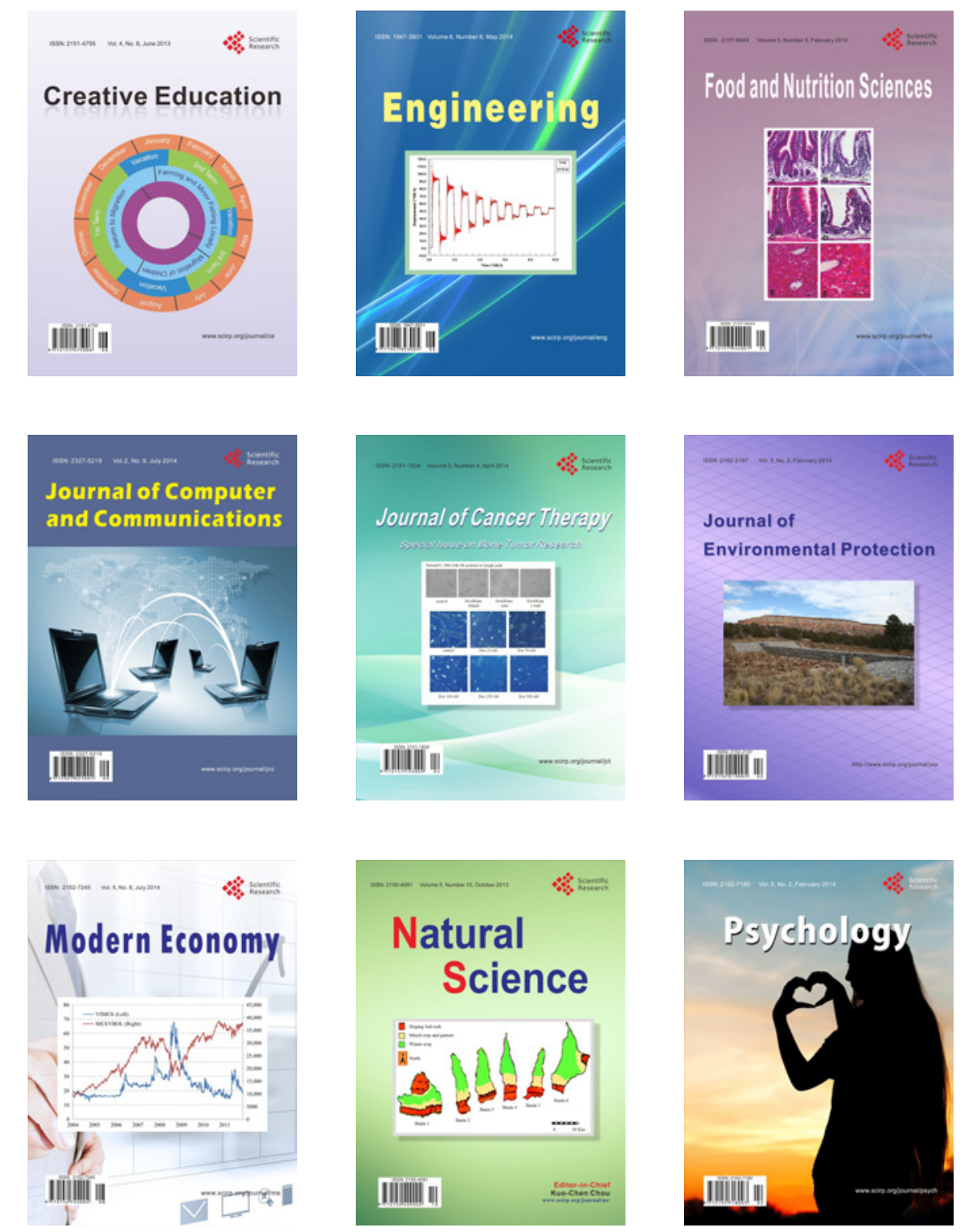